\title{
An Approach of Remote Sensing and GIS for the Delineation of Lineaments in the Suru Valley (Ladakh-Himalayas)
}

Ayaz Mohmood Dar*

Department of Earth science, University of Kashmir, India

\begin{abstract}
An attempt has been made to map a high resolution lineament map of Suru valley (Ladakh) using remote sensing and GIS technology. The study is helpful to establish a new approach and new data acquisition of the lineament mapping, and to compare this remote, inaccessible and lesser known part of the Suru Valley by using the remote sensing source data in association with the field study of the area. In this study, Landsat ETM, Landsat PAN, LISS III images and digital elevation model were used. Different edge enhancement techniques were applied on Landsat ETM and LISS III to better identify the lineaments using different filters while $3 \times 3$ edge enhancement filter, Laplacian filter and sobel filter are mostly used. The enhanced image was merged with the PAN image in order to differentiate between the artificial linear features such as roads, canals etc. and the lineaments. In all, 36 distinct linear features were identified and digitized their latitude, longitude and the direction was analyzed by rose diagram. By the analysis of these lineaments, it was found that all lineaments are in NW-SE direction The Drainage map of the study area, was digitized from the Landsat ETM image, and extracted from DEM's by manual digitization and automatic extraction by different software's which shows Dendritic drainage pattern indicating that the Valley is almost composed of uniform rock type. The mapping of these geological structures improves the existing knowledge about the distribution and direction of the Stress in the Suru Valley.
\end{abstract}

Keywords: A Lineaments; Remote sensing and GIS; Uniform rock types; Drainage pattern

\section{Introduction}

The Himalaya, The highest mountain in the world form a well defined arc to the north of the Indian peninsula, extending for about 2,500 km long from northwest to southeast and features the world's youngest Orogenic belt over the time interval of 60-50 Ma [1-3]. Geologically, Himalaya serves an excellent example of continent-continent collision mountain belt. It has formed as a result of northward drift of the Indian plate from southern hemisphere (Gondwanaland), subduction of intervening oceanic crust of Neo-Tethys followed by the Tertiary continental collision between the Indian and Eurasian continent over a time span of 200 to 50 ma years. The present topographic relief of the Himalaya is attributed to continue convergence of Indian plate beneath the Eurasian plate [4]. On the basis of regional tectonic framework, the entire Himalayan arc can be subdivided into four major tectonic zones, separated by a series of major thrusts $[5,6]$. From South to North, these structural units are: (1) Outer Himalaya (2) Lesser Himalaya (3) Greater or Higher Himalaya and (4) Trans-Himalaya. Apart from Outer, Lesser and Trans-Himalaya, the higher Himalayan crystalline (HHC), occupying the high topography, constitute the main metamorphic belt, and exhibits Barrovian regional metamorphism in Zanskar [7]. It consists of middle-to-deep crustal metamorphic rocks, migmatite and leucogranite and is bounded along the base by the Main Central Thrust (MCT) and along the uppermost margin by the Zanskar Shear Zone(ZSZ) [8]/Trans- Himadri Thrust [9] North Himalayan Normal Fault (Pecher,)/South Tibetan Detachment system (TSZ) lies to the northeast of the HHC on the hanging wall of the ZSZ and the proterozoic Lesser Himalayan Sedimentary Sequence on the footwall of MCT within the Kishtwar Window.

The upper most parts of HHC are exposed along the Suru-Doda Valleys in Jammu and Kashmir and have been named as the Suru Group. This can be traced all along the South western parts of the Zanskar from mune to pensi La and beyond along the Suru valley upto Sankoo. It is predominantly made up of metapelites and metapsammite of upper green schist facies to upper alamandine-amphibiolitefacies and a few granitoid intrusive. The garnet zone rocks are observed near the MCT surrounding the Kishtwar window, whereas rocks of silliminite-K- feldspar zone of deeper structural levels are exposed toward higher topographical levels to the northeast. Grade of metamorphism again lower to garnet grade along the ZSZ in Doda valley. Green schist facies rocks containing mainly garnitiferous mica schist, quartz schist, and calc schist are exposed near the villages Sankoo, Shamakarpo and ZolidakGompa and occasionally intruded by Paleozoic granitoid at Ringdom.The high grades metamorphic rocks are exposed away from the ZSZ around Tangol-Parkachik and along various tributaries of the Doda River.

In the present study a portion of the Kashmir valley has been taken into account to prepare lineament map using satellite images and to analyze the direction of lineaments and find out the relation between lineaments and the drainage pattern of the area.

\section{Study area}

The Suru valley is situated along the north-eastern foothills of the great Himalayan Wall, it extends from Kargil town. Geographically it extends at $34^{\circ} 02^{\prime} \mathrm{N}, 76^{\circ} 16^{\prime} \mathrm{E}$ at an altitude of 3990 meters. The upper valley reaches of the valley, Himalayan slopes to the river bed in riverine formation, Quaint villages of adobe houses straggling dry hillocks surrounded by large tracts of lush crops downward the patches of alpine pastures uphill (Figure 1).

\section{Tectonic setting}

The HHC has an overall dip to the northeast of around 250-350 which combined with relief of up to $4 \mathrm{~km}$ in the Suru valley region, allows $>5 \mathrm{~km}$ (structurally) of right way up middle crust to be studied.

*Corresponding author: Ayaz Mohmood Dar, Department of Earth science, University of Kashmir, India, Tel: 09797264162; E-mail: zeearyans@gmail.com

Received February 26, 2015; Accepted April 08, 2015; Published April 15, 2015

Citation: Dar AM (2015) An Approach of Remote Sensing and GIS for the Delineation of Lineaments in the Suru Valley (Ladakh-Himalayas). J Remote Sensing \& GIS 4: 144. doi:10.4172/2469-4134.1000144

Copyright: (C) 2015 Dar AM. This is an open-access article distributed under the terms of the Creative Commons Attribution License, which permits unrestricted use, distribution, and reproduction in any medium, provided the original author and source are credited. 
Citation: Dar AM (2015) An Approach of Remote Sensing and GIS for the Delineation of Lineaments in the Suru Valley (Ladakh-Himalayas). J Remote Sensing \& GIS 4: 144. doi:10.4172/2469-4134.1000144

The structure of the Suru valley comprises a series of kilometer-scale $\mathrm{S}-\mathrm{W}$ verging recumbent folds, or nappes, such as the Donara nappe, underlain by a lower, later domal structure, the Suru Dome (Figure 2). These folds have mainly flat-lying axial planes but steepen toward the ZSZ to the north. The major SW vergent folds are commonly separated by NE vergent folds that are parasitic to the main folds and locally by ductile shear zones. The recumbent folds interlock in a complex three-dimensional pattern, and the axial planes are all domed by the Suru Dome. The recumbent folds are believed to have formed because of non coaxial simple shear at depth and are premetamorphic to synmetamorphic with respect to the regional M1 kyanite grade Barrovian event. The Suru Dome is similar in style to the other highgraded ones observed throughout the Zanskar [10] and is closely associated with the later M2 metamorphic event and movement on the MCT and ZSZ [10]. Around the edges of the Suru Dome, mineral stretching lineations plunge away from the Dome on all sides, implying a sliding of the overlying. Mineral lineations near the ZSZ trend ENE
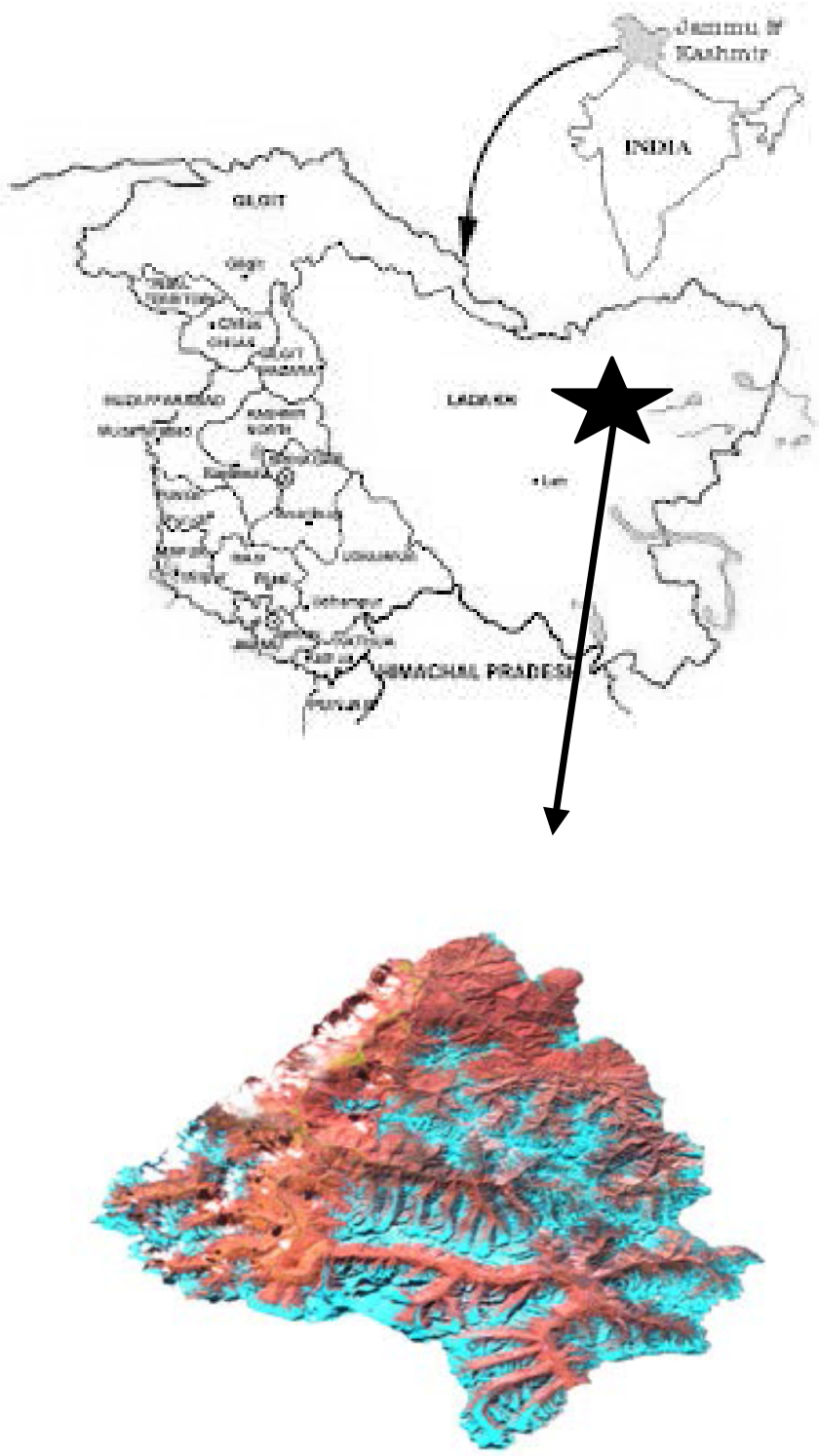

Figure 1: Study area.

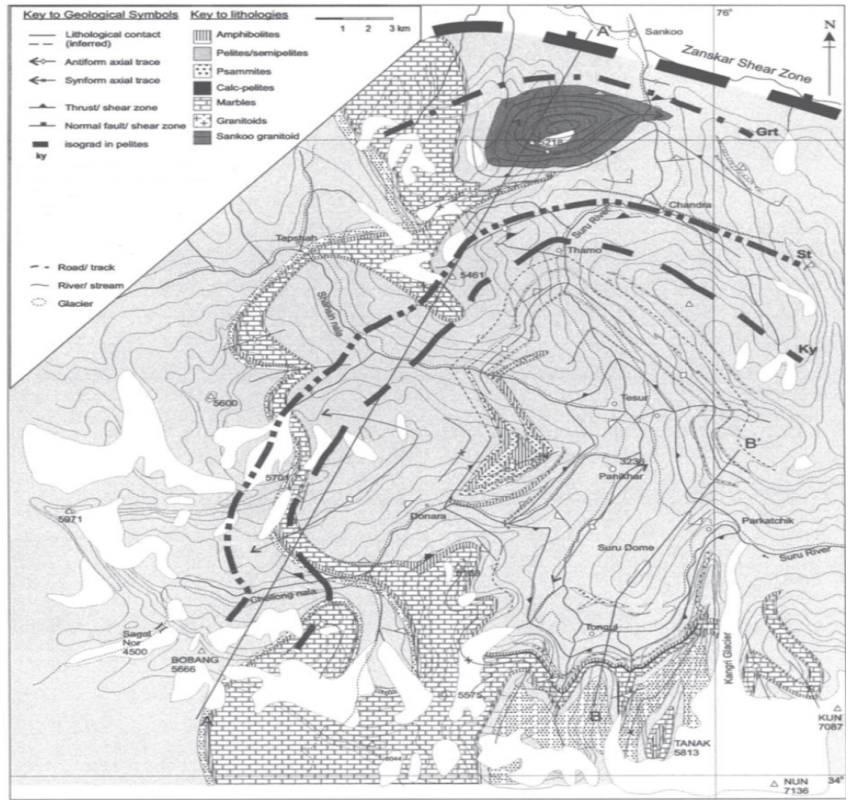

Figure 2: Geological/structural map of Suru Valley around Panikhar, NW Zanskar.

and are related to movement on the ZSZ, which may imply a component of dextral strike slip on the fault as well as a dominant normal sense of shear. This has also been suggested by Walker et al. [11] in SE Zanskar. Minor fold axial planes are generally parasitic to the major fold (nappe) axes, especially in the Chellong nala and are believed to be related to NE-SW shortening and Suru Dome formation.

\section{Methodology}

In the present study following data sets from different sources were used. Landsat ETM image with 30 meter resolution and Landsat ETM+PAN having 15 meter resolution were used to map lineaments and digital elevation model with 90 meter resolution, existing tectonic map of Himalayas and existing lineament map of Kashmir valley were used as secondary data sources. Landsat ETM image with 30 meter resolution and Landsat ETM+ panchromatic image (PAN) with 15 meter resolution were pre-processed and geometrically rectified. Different band combination were used in order to find the bands that are most suitable of mapping of different lineaments and finally FCC image [green (band 2), red (band 3) NIR (band 4)] (spatial resolution 30 $\mathrm{m}$ ) of Landsat ETM were found best for mapping lineaments. Different edge enhancement techniques were used to preserve high frequency elements in the ETM image. The filter that was mainly found useful for identification lineaments was Laplacian filter as shown in Figure 3 although it enhanced the various natural linear features like rivers, discontinuous fractures, ridges etc but along with these lineaments the mountain peaks, roads, field boundaries were also enhanced. Order to differentiate between various artificial linear features like roads, railway tracks etc.

All possible lineaments were digitized on screen from the enhanced image. The latitude, longitude and direction of each lineament were stored during digitization for further statistical analysis. Direction of each lineament was plotted in a compass rose diagram. The resultant lineament map was compared with the existing lineament map of Kashmir valley. The drainage pattern of the study area was digitized 
Citation: Dar AM (2015) An Approach of Remote Sensing and GIS for the Delineation of Lineaments in the Suru Valley (Ladakh-Himalayas). J Remote Sensing \& GIS 4: 144. doi:10.4172/2469-4134.1000144

Page 3 of 4

from the Landsat during digitization high-resolution Landsat ETM+ panchromatic image (spatial resolution $15 \mathrm{~m}$ ) was used to enhance the spatial resolution. Then lineaments were interpretation, mapped of standard color composite (FCC) image. Image and $1^{\text {st }}$ and $2^{\text {nd }}$ order drainage was analyzed using rose diagram and related with lineaments.

\section{Data sets used}

In the present study following data sets from different sources were used:

Landsat ETM image with 30 meter resolution and Landsat ETM+PAN having 15 meter resolution were used to map lineaments and digital elevation model with 90 meter resolution, existing tectonic map of Himalayas and existing lineament map of Kashmir valley were used as secondary data sources.

\section{Results and Discussion}

Lineaments were mapped by the visual image interpretation of standard color composite (FCC) of Landsat ETM Image, LISS image, those was enhanced using $3 \times 3$ edge enhancement filter, Laplacian filter and sobel filter and then merged with the PAN image of 15 meter resolution.

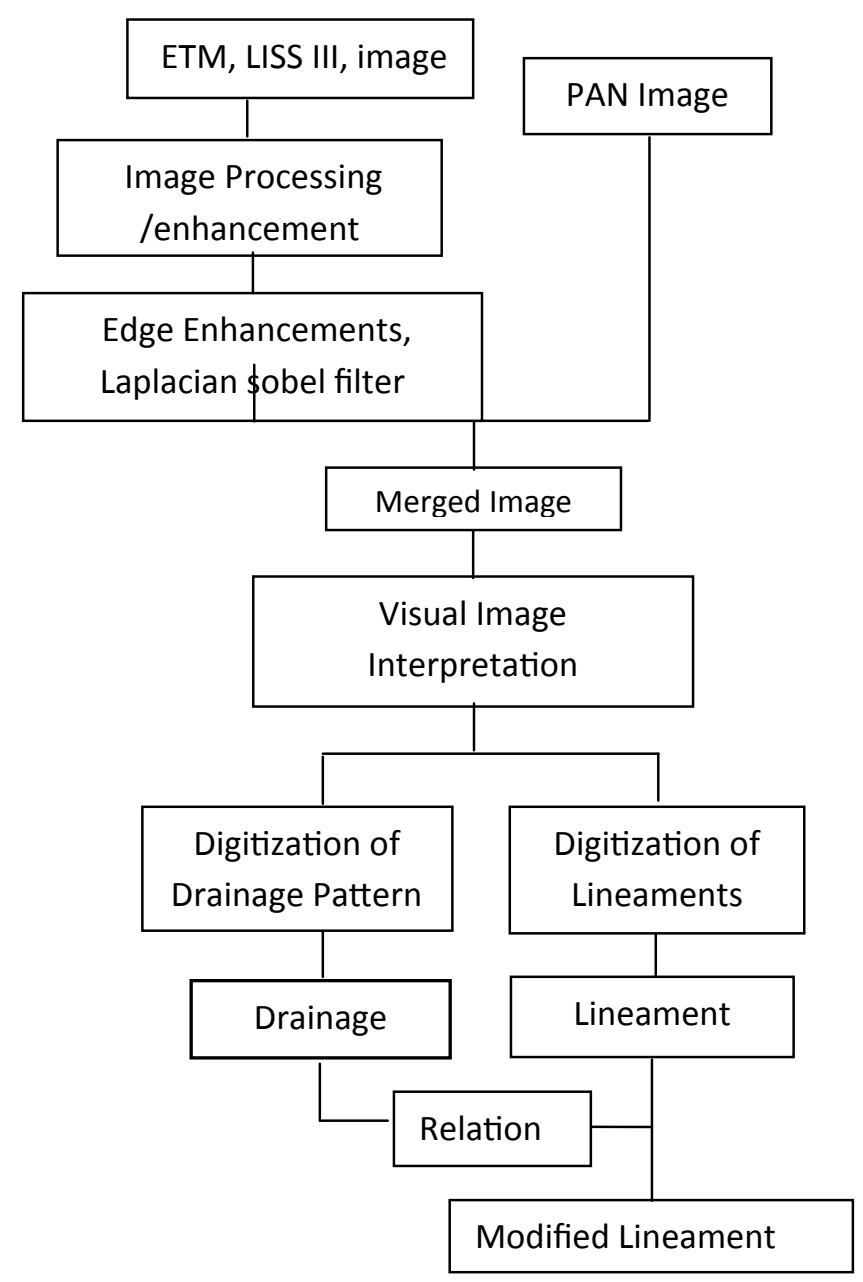

Figure 3: Laplacian filter.
The latitude, longitude and direction of all possible Lineaments were stored during digitization which is shown in Table 1 as description of the lineaments. The study shows 36 linear features as shown in Figure 4 The important thing is that all the liniments lie in NE-SW direction as shown in rose diagram (Figure 5). The analysis of rose diagram shows that all lineaments lies in NE-SW direction and shows the constant stress direction in the study area which is the indication for the need of more geological research.

The Drainage pattern of the study area was digitized from Landsat ETM image and digital elevation model by the manual digitization in Arc Gis software (Figure 6). The main stream and major links were digitized in those software's. The drainage map was also extracted automatically from the Arc Gis in detail and in order to find the missing links in manual digitization (Figure 6). The study area shows the dendritic type of drainage pattern which indicates the almost homogeneous formation of rock types. In order to study the relation between drainage and lineament, the lineaments were overlaid over the drainage map as shown in Figure 7, which revealed that some of important streams flow through these lineaments indicating that the drainage of the study area is structurally controlled.

\section{Conclusion}

differentiate between the artificial linear features such as roads, canals etc. and the lineaments. In all, 36 distinct linear features were identified and digitized their latitude, longitude and the direction was analyzed by rose diagram. By the analysis of these lineaments, it

\begin{tabular}{|c|c|c|}
\hline Lineament & Degrees & Direction \\
\hline 1 & $25^{\circ}$ & $\mathrm{N} 25^{\circ} \mathrm{E}-\mathrm{S} 25^{\circ} \mathrm{W}$ \\
\hline 2 & $20^{\circ}$ & $\mathrm{N} 20^{\circ} \mathrm{E}-\mathrm{S} 20^{\circ} \mathrm{W}$ \\
\hline 3 & $26^{\circ}$ & $\mathrm{N} 26^{\circ} \mathrm{E}-\mathrm{S} 26^{\circ} \mathrm{W}$ \\
\hline 4 & $28^{\circ}$ & $\mathrm{N} 28^{\circ} \mathrm{E}-\mathrm{S} 28^{\circ} \mathrm{W}$ \\
\hline 5 & $35^{\circ}$ & $\mathrm{N} 35^{\circ} \mathrm{E}-\mathrm{S} 35^{\circ} \mathrm{W}$ \\
\hline 6 & $30^{\circ}$ & $\mathrm{N} 30^{\circ} \mathrm{E}-\mathrm{S} 30^{\circ} \mathrm{W}$ \\
\hline 7 & $55^{\circ}$ & $\mathrm{N} 55^{\circ} \mathrm{E}-\mathrm{S} 55^{\circ} \mathrm{W}$ \\
\hline 8 & $55^{\circ}$ & $\mathrm{N} 55^{\circ} \mathrm{E}-\mathrm{S} 55^{\circ} \mathrm{W}$ \\
\hline 9 & $40^{\circ}$ & $\mathrm{N} 40^{\circ} \mathrm{E}-\mathrm{S} 40^{\circ} \mathrm{W}$ \\
\hline 10 & $85^{\circ}$ & $\mathrm{N} 85^{\circ} \mathrm{E}-\mathrm{S} 85^{\circ} \mathrm{W}$ \\
\hline 11 & $20^{\circ}$ & $\mathrm{N} 20^{\circ} \mathrm{E}-\mathrm{S} 20^{\circ} \mathrm{W}$ \\
\hline 12 & $45^{\circ}$ & $\mathrm{N} 45^{\circ} \mathrm{E}-\mathrm{S} 45^{\circ} \mathrm{W}$ \\
\hline 13 & $44^{\circ}$ & $\mathrm{N} 44^{\circ} \mathrm{E}-\mathrm{S} 44^{\circ} \mathrm{W}$ \\
\hline 14 & $46^{\circ}$ & $\mathrm{N} 46^{\circ} \mathrm{E}-\mathrm{S} 46^{\circ} \mathrm{W}$ \\
\hline 15 & $40^{\circ}$ & $\mathrm{N} 40^{\circ} \mathrm{E}-\mathrm{S} 40^{\circ} \mathrm{W}$ \\
\hline 16 & $62^{\circ}$ & $\mathrm{N} 62^{\circ} \mathrm{E}-\mathrm{S} 62^{\circ} \mathrm{W}$ \\
\hline 17 & $20^{\circ}$ & $\mathrm{N} 20^{\circ} \mathrm{E}-\mathrm{S} 20^{\circ} \mathrm{W}$ \\
\hline 18 & $45^{\circ}$ & $\mathrm{N} 45^{\circ} \mathrm{E}-\mathrm{S} 45^{\circ} \mathrm{W}$ \\
\hline 19 & $60^{\circ}$ & $\mathrm{N} 60^{\circ} \mathrm{E}-\mathrm{S} 60^{\circ} \mathrm{W}$ \\
\hline 21 & $20^{\circ}$ & $\mathrm{N} 20^{\circ} \mathrm{E}-\mathrm{S} 20^{\circ} \mathrm{W}$ \\
\hline 23 & $05^{\circ}$ & $\mathrm{N} 05^{\circ} \mathrm{E}-\mathrm{S} 05^{\circ} \mathrm{W}$ \\
\hline 24 & $85^{\circ}$ & $\mathrm{N} 85^{\circ} \mathrm{E}-\mathrm{S} 85^{\circ} \mathrm{W}$ \\
\hline 25 & $35^{\circ}$ & $\mathrm{N} 35^{\circ} \mathrm{E}-\mathrm{S} 35^{\circ} \mathrm{W}$ \\
\hline 27 & $25^{\circ}$ & $\mathrm{N} 25^{\circ} \mathrm{E}-\mathrm{S} 25^{\circ} \mathrm{W}$ \\
\hline 28 & $15^{\circ}$ & $\mathrm{N} 15^{\circ} \mathrm{E}-\mathrm{S} 15^{\circ} \mathrm{W}$ \\
\hline 31 & $40^{\circ}$ & $\mathrm{N} 40^{\circ} \mathrm{E}-\mathrm{S} 40^{\circ} \mathrm{W}$ \\
\hline 32 & $15^{\circ}$ & $\mathrm{N} 15^{\circ} \mathrm{E}-\mathrm{S} 15^{\circ} \mathrm{W}$ \\
\hline 33 & $07^{\circ}$ & $\mathrm{N} 07^{\circ} \mathrm{E}-\mathrm{S} 07^{\circ} \mathrm{W}$ \\
\hline 34 & $20^{\circ}$ & $\mathrm{N} 20^{\circ} \mathrm{E}-\mathrm{S} 20^{\circ} \mathrm{W}$ \\
\hline 35 & $20^{\circ}$ & $\mathrm{N} 20^{\circ} \mathrm{E}-\mathrm{S} 20^{\circ} \mathrm{W}$ \\
\hline 36 & $05^{\circ}$ & $\mathrm{N} 05^{\circ} \mathrm{E}-\mathrm{S} 05^{\circ} \mathrm{W}$ \\
\hline
\end{tabular}


Citation: Dar AM (2015) An Approach of Remote Sensing and GIS for the Delineation of Lineaments in the Suru Valley (Ladakh-Himalayas). J Remote Sensing \& GIS 4: 144. doi:10.4172/2469-4134.1000144

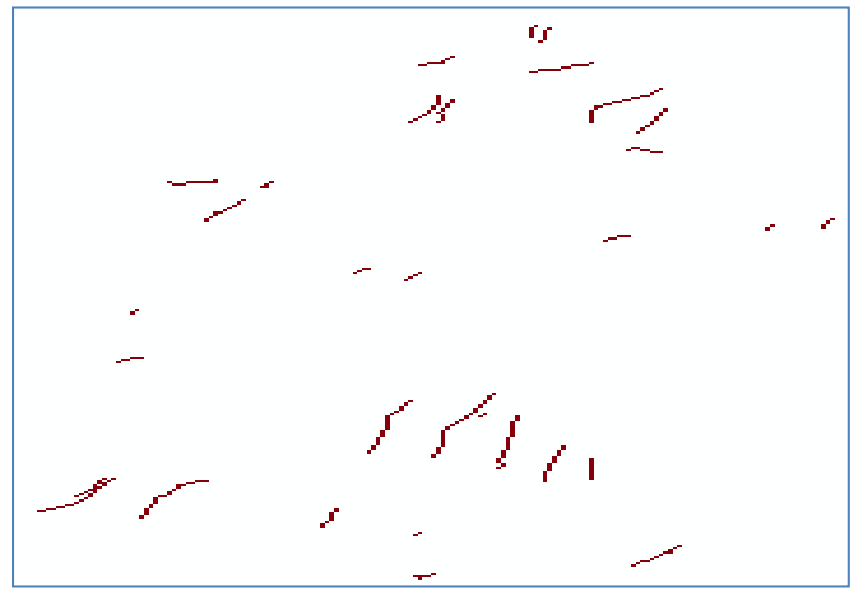

Figure 4: The lineament map of Suru Valley.

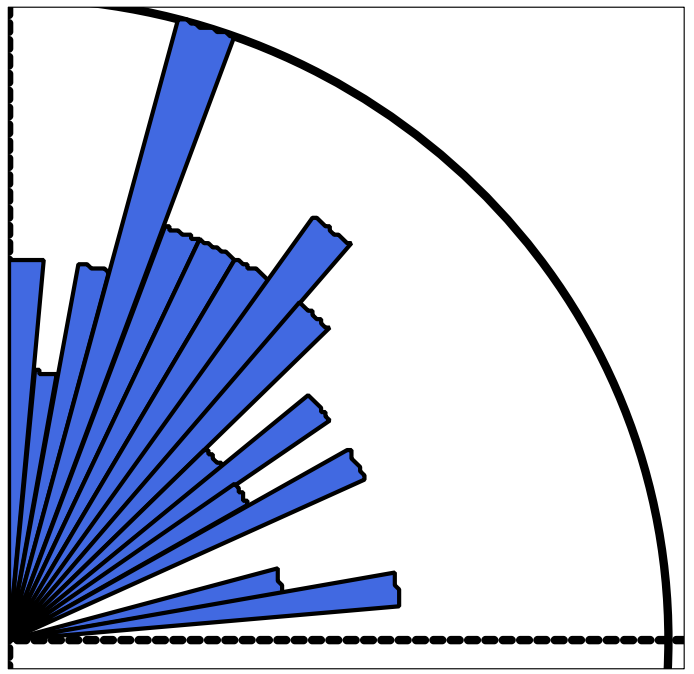

Figure 5: Rose diagram of lineaments.
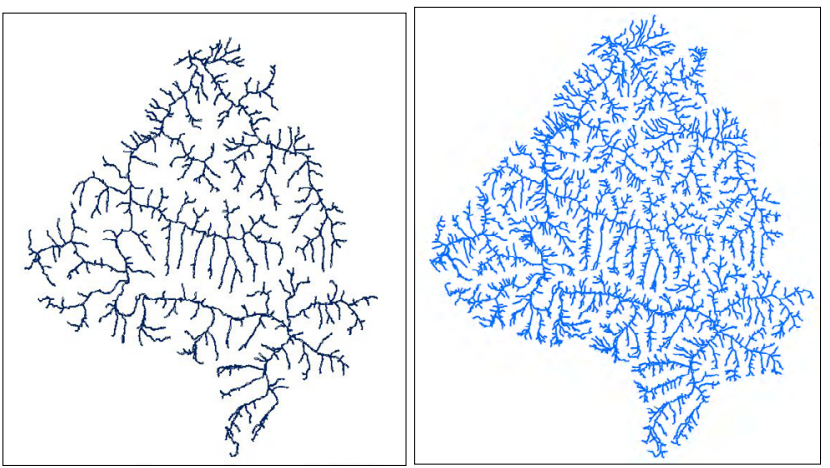

Figure 6: The manually digitized (left) and automatically extracted (right) map of Suru valley.

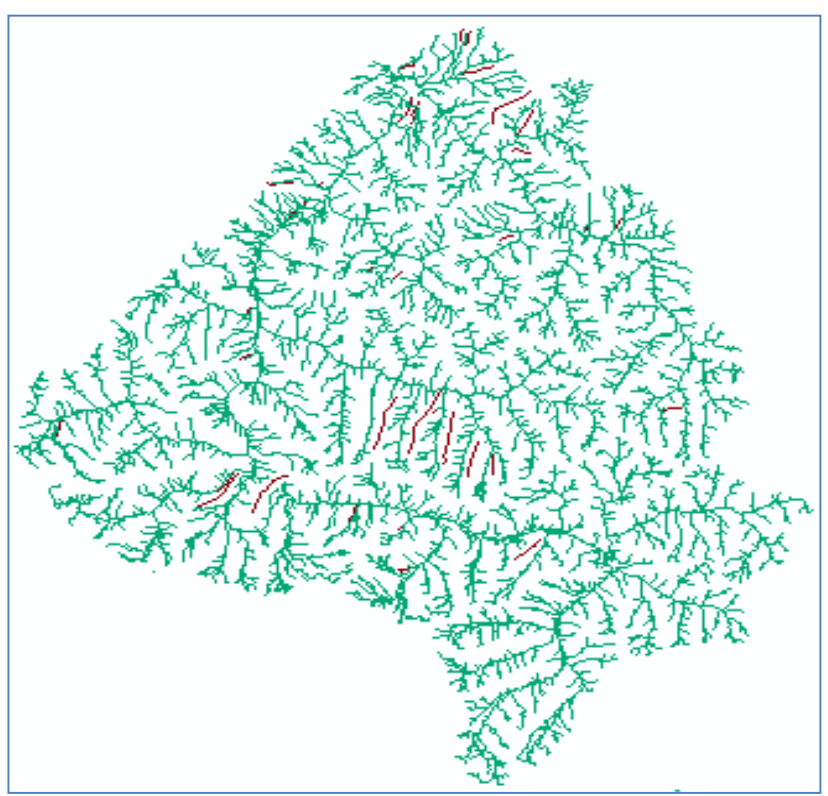

Figure 7: Comparison between drainage and lineaments.

was found that all lineaments are in NW-SE direction The Drainage map of the study area, was digitized from the Landsat ETM image, and extracted from DEM's by manual digitization and automatic extraction by different software's which shows Dendritic drainage pattern indicating that the Valley is almost composed of uniform rock type. By the analysis of lineaments by rose diagram it clearly indicates the uniform stress direction which in turn indicates the need of more study in study area as well as adjacent areas.

\section{References}

1. Valdiya KS (1988) Geology of Kumaon Lesser Himalaya. Wadia Inst. of Himalayan Geol, Dehradun, India.

2. Thakur VC (1980) Tectonics of the Central Crystal- lines of western Himalaya Tectonophysics 62: 141-154.

3. Searle MP, Rex AJ (1989) Thermal model for the Zanskar Himalaya. J Metamorph Geology 7: 127-134.

4. Searle MP (1986) Structural evolution and sequence of thrusting in the higher Himalaya,Tibetan-Tethys and Indus suture zones of Zanskar and Ladakh, WestHimalaya. Journal of Structural Geology 8: 923-936.

5. Wadia DN (1936) Trend-line Himalayas, Himal. J Oxford University Press, Vol III.

6. Thakur VC, Rawat BS, Islam R (1990) Zanskar Crystallines-Some observations on its lithostratigraphy, deformation metamorphism and regional framework. Journal of Himalayan Geology 1: 11-25.

7. Thakur VC, Gupta VC (1990) Regional stratigraphy, paleontology and structure of Kashmir and Ladakh Himalayas. Contr Him Geol.

8. Herren E (1987) The Zanskar shear zone: Northeast-Southwest extension within the higher Himalaya (Ladakh, India). Geology 15: 409-413.

9. Valdiya KS (1980) Geology of Kumaun Lesser Himalaya. WIHG, Dehradun 291.

10. Searle MP, Waters DJ, Rex DC, Wilson RN (1992) Pressure, temperature and time constraintso $\mathrm{n}$ Himalayanm etamorphism from eastern Kashmir and western Zanskar. J Geol Soc London 149: 753-773.

11. Walker CB, Searle MP, Waters DJ (2001) An integrated tectonother- mal mode for the evolution of the High Himalaya in western Zanskar with constraints from thermobarometry and metamorphic modeling. Tectonics 20: 810-833. 